\title{
The role of work life balance for organizational commitment
}

\author{
Inge Hutagalunga, Mochamad Soelton ${ }^{\mathrm{b}^{*}}$ and Ayu Octaviani ${ }^{\mathrm{c}}$
}

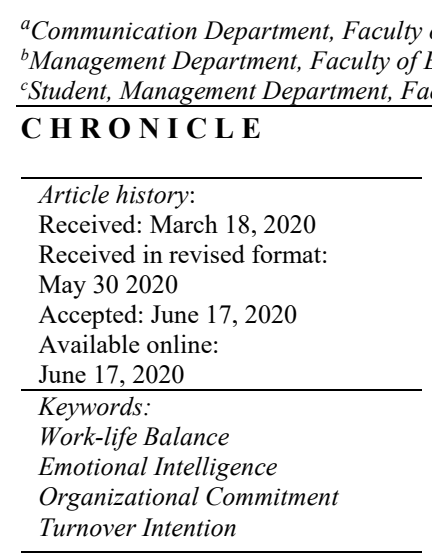

\section{Introduction}

Human resources are individuals or groups who work in companies or organizations. Human resources have a significant contribution in increasing the competitiveness of companies, therefore human resources are people who are adaptive and responsive to changes that occur. Human resources in the company must always be oriented towards the vision and mission of the company where they work. Human resources in the company are one of the assets and said to be the most important, because human resources themselves determine the direction and objectives of the company and determine the effectiveness and productivity of the company, (Soelton et al., 2020b; Nurhayati et al., 2017; Hafid \& Prasetio, 2017). In business competition, companies need reliable and quality human resources, therefore human resources need to be managed and fostered well so that they can carry out their work as much as possible so that human resources contribute optimally to produce high performance for the progress of the company where they work (Soelton et al., 2020a). One way to manage good resources is to minimize employee turnover by taking into account all the factors that cause employees to turnover intention (Suzabar, 2020; Hafid \& Prasetio, 2017). Based on employee turnover data for the period 2015-March 2019, the number of employees who resign every year is increasing and the highest occurred in 2018 where as many as 17 people resigned. Based on the results of the author's interview with human resource development (HRD), the reasons for their resignation varied. Some want to move out of town, look for better jobs, look for work close to home and because they cannot balance and divide their time between work at home and work at the office. One of the factors influencing exit intention is organizational commitment, where organizational commitment can predict organizational output variables such as intention to leave, (Nurhayati et al., 2017; Adi \& Ratnasari, 2015). Besides demanding employees to be able to carry out every corporate goal that must be achieved, the company must also pay attention to the flexibility of the work of employees in running their social lives (Rene \& Wahyuni, 2018). 
Based on data in June and December there were 2 employees who did not go to work without information (alpha), the highest number of employees left in July was 21 employees and as many as 38 employees came late to the office in June. Late is the highest thing that happened in 2018, employees who are late will be subject to sanctions in the form of salary deductions. For example, if an employee is 1 minute late from the agreed working hour, the company applies a cut of Rp 239 per minute. In the reality, the absence of work-life balance causes poor performance and more employee absences. Work-life balance programs managed by HR Managers may provide positive advantages, such as attracting more prospective new employees, reducing turnover and absenteeism, increase employee performance and involvement in the program and company goals.

As an employee who works in a company, a good work-life balance may occur while the employee has good emotional intelligence. Work-life balance is associated with a broad concept which involves setting the right priorities between work (career and ambition) on one side and life (happiness, leisure, family and spiritual development) on the other side. In the world of organization, it is not surprising if someone takes two important roles at once, namely between work and personal matters (family). It does look complex to be lived, but if someone can balance the two things, the work will feel easy and peaceful for everyone. In fact, when someone cannot balance work priorities with personal (family) priorities, it is feared that they can interfere with the work process. Emotional intelligence is currently an interesting subject in the field of human resource management (Ardiansyah \& Sulistyowati, 2018). People who have emotional intelligence will be able to face challenges and make a human being full of responsibility, productive, and optimistic in facing and solving problems, where these things are needed in the work environment. Employees who have a tendency towards turnover intention, usually have a low commitment to the organization where he works. In the world of work, one's commitment to an organization or company is often a very important issue.

\section{Literature review}

\subsection{Work-life Balance}

Work-life balance is a condition when someone feels the involvement and satisfaction of the same role in the work domain and family, with minimal conflict, because of his/her ability to manage various responsibilities and determine priorities (Handayani et al., 2015). Moorhead and Griffin (2013) revealed that work-life balance is a person's ability to balance work demands with personal and family needs. Fisher et al. (2009) state that work-life balance is something that someone does in dividing time both in the workplace and other activities outside of work in which there is individual behavior where this can be a source of personal conflict and a source of energy for oneself. According to Fisher et al. (2009), work-life balance has 4 dimensions:

- Work Interference with Personal Life: This dimension refers to the extent to which work can interfere with an individual's personal life.

- Personal Life Interference with Work: This dimension refers to the extent to which an individual's personal life interferes with his work life.

- Personal Life Enhancement of Work: This dimension refers to the extent to which a person's personal life can improve individual performance in the world of work.

- Work Enhancement of Personal Life: This dimension refers to the extent to which work can improve the quality of an individual's private life.

\subsection{Emotional Intelligence}

Emotional intelligence is an emotional ability which includes the ability to control oneself, have endurance when facing a problem, be able to control impulses, motivate yourself, be able to regulate moods, the ability to empathize and foster relationships with others (Goleman, 2015; Do et al., 2020). According to McShane and Von Glinow (2010) emotional intelligence is a set of abilities to feel and express emotions, assimilate emotions in thinking, understanding and reason with emotions, and connect emotions in oneself and others. According to (Mayer and Salovey in Majdalani and Maamari, 2016) emotional intelligence is a cognitive ability that is the ability to understand, recognize and evaluate the meaning of emotions in order to make sense and solve problems.

According to Goleman (2015), the dimensions of emotional intelligence are follows,

- Recognize self-emotions: Self-awareness is recognizing feelings when they occur and is the basis of emotional intelligence. The ability to monitor feelings over time is important for psychological insight and self-understanding. Managing emotions: Handling feelings so they can be properly expressed are skills that depend on self-awareness. People who are bad at this skill will continue to fight against moody feelings, while those who are smart can get back up much faster than the decline and fall in life. Motivate yourself: Organizing emotions as a means to an end is very important in terms of giving attention, to motivating someone and control, and to be creative. Recognize other people's emotions: Empathic people are better able to pick up on hidden social signals that signal what others need or want. Such people are suitable for nursing, teaching, sales, and management jobs. Build relationships: The art of building relationships, for the most part, is a skill to manage the emotions of others. This is a skill that supports 
interpersonal popularity, leadership, and success. People who are good at this skill will succeed in any field that relies on seamless association with others.

\subsection{Organizational Commitment}

Organizational commitment is one of the important factors in any organization and plays an important role in improving the quality and productivity of employees. The high commitment of the aforementioned employees is inseparable from the employees' trust in management's good treatment of them, namely the existence of a management approach to human resources as valuable assets and not solely as commodities that can be exploited as management wishes. According to Mahiri (2016), organizational commitment is a situation where employees take sides and care for a particular organization and its goals, and intend to maintain its membership in the organization. According to Newstrom (2011) in Wibowo (2017) it provides the same understanding between organizational commitment and employee loyalty, namely as a level where workers identify with the organization. Workers identify with the organization showing that workers mix well and in accordance with organizational ethics and expectations that they experience a feeling of oneness with the company. Luthans et al. (2011) express that organizational commitment has three basic dimensions that are closely related as follows:

- Affective Commitment: a desire to remain a member of an organization because of its emotional attachment and involvement with the organization. Normative Commitment: a desire to remain a member of an organization because of awareness of the costs associated with leaving the organization. Continuance Commitment: a desire to remain a member of an organization because of the feeling of having an obligation to remain with the organization.

\subsection{Turnover Intention}

Turnover intention is a desire of employees to quit the membership of the organization and change jobs by receiving wage income. According to Wirawan (2015) turnover intention is the tendency or intention of employees to stop working from work voluntarily according to their own choice. Turnover intention is the permanent voluntary or involuntary resignation of an organization. Turnover intention is something that is not desired by the company. Turnover intention has a negative impact on the organization because it can create instability in the condition of employees, create a work environment that is not conducive and also have an impact on increasing the cost of human resources (Soelton et al., 2020a,b; Nguyen, 2020). According to Mobley (2011) there are two dimensions that are closely related to turnover intention mentioned as follows:

- External Factors: higher salary, self-potential development and better offer,

- Internal Factors: working environment, worker's relationship, compensation, work load.

\section{Conceptual framework}

According to the literature review, the proposed model of this paper is shown in Fig. 1.

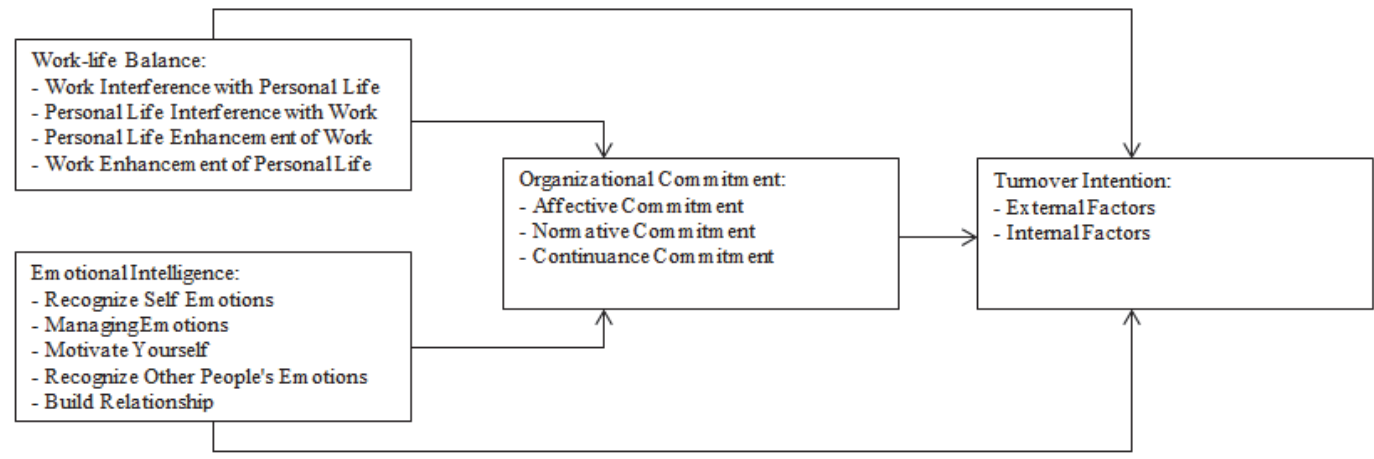

Fig. 1. Conceptual framework

Regarding the previous, the following hypotheses are proposed:

H1 : Work Life Balance has a positive influence on Organizational Commitment.

H2 : Emotional Intelligence has a positive influence on Organizational Commitment.

H3 : Work Life Balance has a positive influence on Turnover Intention.

H4 : Emotional Intelligence has a positive influence on Turnover Intention.

H5 : Organizational Commitment has a positive influence on Turnover Intention. 


\section{Methodology}

The research process begins with the activity of identifying the problem at the place that will be used as a research location, the formulation of the problem identified, the preparation of the theoretical basis that strengthens the foundation in variables, the preparation of methods in data collection, the preparation of instruments, until the determination of statistical testing techniques used. In the preparation of this study, researchers used a causal analysis method. Causal analysis is a causal relationship. Research conducted to find out about the effect of one or more independent variables (independent variables) on the dependent variable (the dependent variable). The approach taken in this research is a quantitative approach. The total population used in this study were all employees of PT. Grafitama Deltakreasi numbered 60 people. In this research, data collection was carried out through several steps, questionnaires, interviews, documentation, literature study. The analytical method used in this research is the Component or Variance Based Structural Equation Model where the data processing uses the Partial Least Square (Smart-PLS) version 3.2.8 PLS program. The result of the validity test are as follows:

Table 3

Validity Test Results

\begin{tabular}{|c|c|c|c|c|}
\hline Variable & Dimension & Item & Correlation & Description \\
\hline \multirow{12}{*}{ Work-life Balance } & \multirow{4}{*}{ Work Interference with Personal Life } & W2 & 0.663 & Valid \\
\hline & & W3 & 0.724 & Valid \\
\hline & & W4 & 0.717 & Valid \\
\hline & & W5 & 0.759 & Valid \\
\hline & \multirow{3}{*}{ Personal Life Interference with Work } & W6 & 0.556 & Valid \\
\hline & & W7 & 0.819 & Valid \\
\hline & & W8 & 0.743 & Valid \\
\hline & \multirow{2}{*}{ Personal Life Enhancement of Work } & W9 & 0.821 & Valid \\
\hline & & W10 & 0.766 & Valid \\
\hline & \multirow{3}{*}{ Work Enhancement of Personal Life } & W12 & 0.525 & Valid \\
\hline & & W13 & 0.807 & Valid \\
\hline & & W14 & 0.804 & Valid \\
\hline \multirow{12}{*}{ Emotional Intelligence } & \multirow{3}{*}{ Recognize Self Emotions } & KE2 & 0.691 & Valid \\
\hline & & KE3 & 0.896 & Valid \\
\hline & & KE4 & 0.711 & Valid \\
\hline & Managing Emotions & KE5 & 0.633 & Valid \\
\hline & \multirow{2}{*}{ Motivate Yourself } & KE8 & 0.734 & Valid \\
\hline & & KE9 & 0.729 & Valid \\
\hline & \multirow{2}{*}{ Recognize Other People's Emotions } & KE10 & 0.837 & Valid \\
\hline & & KE11 & 0.652 & Valid \\
\hline & \multirow{4}{*}{ Build Relationship } & KE14 & 0.648 & Valid \\
\hline & & KE15 & 0.628 & Valid \\
\hline & & KE16 & 0.694 & Valid \\
\hline & & KE18 & 0.873 & Valid \\
\hline \multirow{6}{*}{$\begin{array}{c}\text { Organizational } \\
\text { Commitment }\end{array}$} & \multirow{4}{*}{ Affective } & $\mathrm{KO} 1$ & 0.870 & Valid \\
\hline & & $\mathrm{KO} 2$ & 0.921 & Valid \\
\hline & & $\mathrm{KO} 3$ & 0.922 & Valid \\
\hline & & KO5 & 0.703 & Valid \\
\hline & \multirow{2}{*}{ Continuance } & $\mathrm{KO} 7$ & 0.904 & Valid \\
\hline & & KO8 & 0.811 & Valid \\
\hline \multirow{6}{*}{ Turnover Intention } & \multirow{2}{*}{ External Factors } & TI1 & 0.847 & Valid \\
\hline & & TI2 & 0.843 & Valid \\
\hline & \multirow{4}{*}{ Internal Factors } & TI3 & 0.832 & Valid \\
\hline & & TI4 & 0.728 & Valid \\
\hline & & TI5 & 0.688 & Valid \\
\hline & & TI6 & 0.625 & Valid \\
\hline
\end{tabular}

Source: From data processing (2019)

Based on Table 1 above, the calculations of the item score correlation with the total score show that the validity coefficient is greater than 0.70 , so all the items used to measure the said variables are considered as valid. The reliability test of this research data is based on Cronbach's Alpha coefficient method. The Cronbach's Alpha coefficient is the reliability coefficient that are most commonly used because the coefficient will indicate the variance of items with either correct or incorrect format such as Likert scale format.

Table 4

Reliable Test Result

\begin{tabular}{|c|c|c|c|}
\hline Variable & Cronbach Alpha's & Composite Reliability & Information \\
\hline Emotional Intelligence & 0.920 & 0.932 & Reliable \\
\hline Organizational Commitment & 0.928 & 0.944 & Reliable \\
\hline Turnover Intention & 0.855 & 0.893 & Reliable \\
\hline Work Life Balance & 0.918 & 0.931 & Reliable \\
\hline
\end{tabular}


The results of Cronbach alpha indicate that all values are greater than 0.70 which confirms the reliability of the survey.

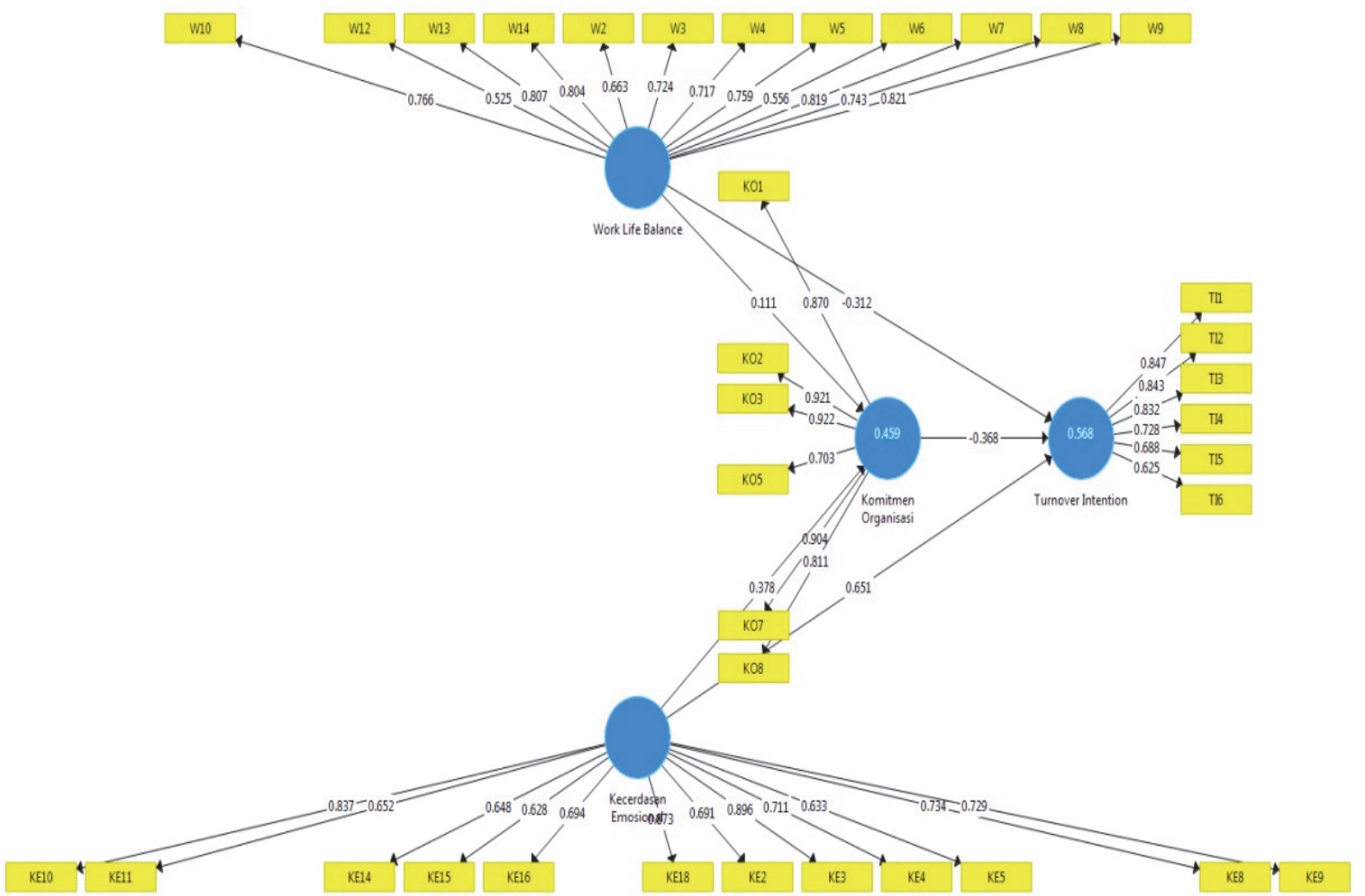

Source: From Data Processing (2019)

Fig. 2. The Correlation of Variables

\section{Results and discussion}

The results of the modification of the convergent validity test in Fig. 2, indicate that all indicators meet the convergent validity because it has a loading factor value above 0.70 .

\section{Table 5}

Goodness of Fit Model (GoF)

\begin{tabular}{lccc}
\hline \multicolumn{1}{c}{ Variable } & AVE & Composite Reliability & Cronbach's Alpha \\
\hline Emotional Intelligence & 0.537 & 0.932 & 0.920 \\
Organizational Commitment & 0.738 & 0.944 & 0.928 \\
Turnover Intention & 0.586 & 0.893 & 0.855 \\
Work Life Balance & 0.535 & 0.931 & 0.918 \\
\hline
\end{tabular}

Source: Form data processing (2019)

Predictive relevance value is obtained by the formula:

$Q^{2}=1-(1-R 1)\left(1-R_{p}\right)=1-(1-0.459)(1-0.568)=1-(0.541)(0.432)=0.7663$

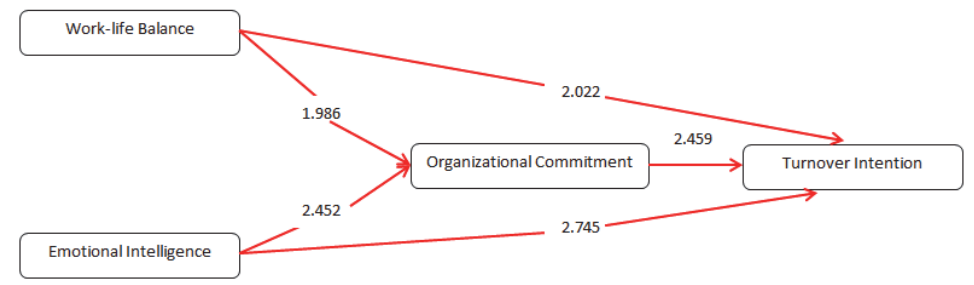

Source: Form data processing (2019)

Fig. 3. The Testing Result 
According to the results of Table 5, which are associated with Goodness of Fit all values of R-Square confirm that the criteria are strong, with a large Q value and it can be concluded that the proposed model is supported by empirical research which is quite suitable. Likewise, the AVE values are $>0.5$, indicating that all variables in the model are estimated to meet the discriminant validity criteria. The value of Composite Reliability and Cronbach's Alpha for each variable is $>0.70$ (above 0.70 ) meaning that all variables studied are classified as reliable. From the results of hypothesis testing, it was revealed that emotional intelligence has the greater influence on organizational commitment compared to work-life balance. Emotional intelligence has the greater influence on turnover intention compared with work-life balance and organizational commitment.

Table 6

Hypothesis Testing Results

\begin{tabular}{|c|c|c|c|c|c|}
\hline & $\begin{array}{l}\text { Original } \\
\text { Sample }\end{array}$ & $\begin{array}{c}\text { Standard } \\
\text { Deviation }\end{array}$ & T-Statistics & P Values & Conclusion \\
\hline Work Life Balance $\rightarrow$ Organizational Commitment & 0.111 & 0.136 & 1.986 & 0.047 & Positive - Significant \\
\hline Emotional Intelligence $\rightarrow$ Organizational Commitment & 0.378 & 0.236 & 2.452 & 0.002 & Positive - Significant \\
\hline Work Life Balance $\rightarrow$ Turnover Intention & -0.312 & 0.205 & 2.022 & 0.007 & Negative - Significant \\
\hline Emotional Intelligence $\rightarrow$ Turnover Intention & 0.651 & 0.273 & 2.745 & 0.002 & Positive - Significant \\
\hline Organizational Commitment $\rightarrow$ Turnover Intention & -0.368 & 0.150 & 2.459 & 0.014 & Negative - Significant \\
\hline
\end{tabular}

Based on the testing result above, emotional intelligence has the most significant influence on organizational commitment followed with work-life balance.

\section{1) Effect of Work-Life Balance on Organizational Commitment}

Based on the hypothesis test in this study, the T-statistic value was 1.986 , the original sample value was 0.111 , and the $\mathrm{P}$ value was 0.047 . The T-statistic value is greater than the T-table value of 1.96 , the original sample value shows a positive value, and the $\mathrm{P}$ value indicates less than 0.05 , these results indicate work-life balance has a positive and significant effect on organizational commitment. Hill et al. (2001) revealed that it was very beneficial working hours because it was beneficial to create organizational commitment to employees and achieve work life balance. A positive work-life balance can lead to increased morale, increase productivity, increase organizational commitment and reduce absenteeism. In line with this, a study conducted by Allen in Webber et al., (2010) shows the balance of work life is closely related to the level of organizational commitment to employees to determine perceptions in how employees support the organization.

\section{2) Effects of Emotional Intelligence on Organizational Commitment}

Based on the hypothesis test in this study the results obtained T-value a statistic of 2,452, an original sample value of 0,378 , and a $\mathrm{P}$ value of 0,002 . The T-statistic value is greater than the T-table value of 1.96 , the original sample value shows a positive value, and the $P$ value indicates less than 0.05 , this result indicates a positive and significant emotional intelligence on organizational commitment. Rustamadji and Omar (2019) revealed that individuals with higher emotional intelligence were higher in their organizations. The statement is in accordance with research conducted by other studies, which shows positive emotional intelligence on organizational commitment.

\section{3) Effect of Work-Life Balance on Turnover Intentions}

Based on the hypothesis test in this study the results obtained T-statistic value of 2.022 , the original sample value of -0.312 , and the value of $P$ value of 0.007 . The T-statistic value is greater than the T-table value of 1.96 , the original sample value shows a negative value, and the $\mathrm{P}$ value of the value indicates less than 0.05 , these results indicate that work-life balance has a negative and significant effect on turnover intention. This study concludes that work-life balance is low, so turnover intention will increase, and vice versa. Several other researchers who got the same findings in their research reported (Allam, 2019).

\section{4) Effects of Emotional Intelligence on Turnover Intention}

Based on the hypothesis test in this study the results obtained T-statistic value of 2.745 , the original sample value of 0.651 , and the value of $P$ value of 0.002 . The T-statistic value is greater than the T-table value of 1.96 , the original sample value shows a positive value, and the $\mathrm{P}$ value indicates less than 0.05 , this result indicates a positive and significant emotional intelligence on turnover intention (Bilginoğlu \& Yozgat, 2018).

\section{5) Effect of Organizational Commitment on Turnover Intention}

Based on the hypothesis test in this study, the T-statistic value was 2.459 , the original sample value was -0.388 , and the $\mathrm{P}$ value was 0.014 . The T-statistic value is greater than the T-table value of 1.96 , the original sample value shows a negative value, and at the $\mathrm{P}$ value the value indicates less than 0.05 , these results indicate an organizational commitment that produces a negative and significant effect on turnover intentions. Organizations that can give full attention and make the company to the organization will get the company's commitment. 


\section{Conclusion and recommendation}

\subsection{Conclusion}

This study has tried to analyze variables related to work life balance, emotional intelligence, organizational commitment, and turnover intention. The results of this study were obtained from research on the employees. From the results of calculations in this study, the following conclusions can be drawn:

1. Work life balance has a significant positive effect on organizational commitment on the employees. This means that higher work-life balance can directly influence the increase in organizational commitment in the company.

2. Emotional intelligence has a significant positive effect on organizational commitment in the employees. This means that if individuals have higher emotional intelligence, then they will be more committed to the organization.

3. Work life balance has a significant negative effect on turnover intention. This means that the lower work-life balance, the higher the intention to resign (turnover intention) in a company.

4. Emotional intelligence has a significant positive effect on turnover intention. This means that employees who have high emotional intelligence will tend to leave their work so it can be said that the level of turnover intention that occurs will increase.

5. Organizational commitment has a significant negative effect on turnover intention. This means that higher level of caring and employee confidence in committing to the sustainability of the company will reduce the employee's desire to leave (turnover intention).

\subsection{Recommendation}

Based on the conclusions above, it can be put forward some suggestions that are taken into consideration for campony and for future researchers:

1. The company must arrange the employee's work time, especially if there is overtime. To provide time balance between work and family for employees.

2. Companies must minimize conflicts that occur with employees, such as holding gatherings to strengthen relations between employees.

3. The company must bind employees by making employees part of the company, such as taking into consideration the suggestions given by employees to the company.

4. The company should provide career paths in the company, to provide employee enthusiasm for work.

\subsection{Further Research Suggestions}

This study has aimed to examine and analyze the influence of work-life balance and emotional intelligence on turnover intention with organizational commitment as an intervening variable. The results have shown that work-life balance has a positive and significant effect on organizational commitment. Emotional intelligence has a positive and significant effect on organizational commitment. Work-life balance has a negative and significant effect on turnover intention. Emotional intelligence has a positive and significant effect on turnover intention. Organizational commitment has a negative and significant effect on turnover intention. According to the hypothesis we developed, we can look for it in the future with a variety of variables and more population

\section{References}

Adi, A. Z., \& Ratnasari, S. R. (2015). Pengaruh Komitmen Organisasi, Penghargaan dan Kepuasan Kerja terhadap Perputaran Karyawan pada Perbankan Syariah di Kota Batam. Etikonomi, 14(1), 35-50.

Allam, Z. (2019). An inquisitive enquiry of work-life balance of employees: Evidences from Kingdom of Saudi Arabia. Management Science Letters, 9(2), 339-346.

Ardiansyah, Y., \& Sulistiyowati, L. H. (2018). Pengaruh Kompetensi dan Kecerdasan Emosional Terhadap Kinerja Pegawai. Jurnal Inspirasi Bisnis dan Manajemen, 2(1), 91-100.

Bilginoğlu, E., \& Yozgat, U. (2018). Impact of strategic leadership on organizational performance, strategic orientation and operational strategy. Management Science Letters, 8(12), 1331-1344.

Do, D., Ha, H., Tran, T., \& Nguyen, T. (2020). Motivation for accounting human resources by material stimulation: The case of accounting service firms in Hanoi, Vietnam. Accounting, 6(1), 23-32.

Fisher, G. G., Bulger, C. A., \& Smith, C. S. (2009). Beyond work and family: a measure of work/nonwork interference and enhancement. Journal of occupational health psychology, 14(4), 441.

Goleman, D. (2015). Emotional Intelligence : Kecerdasan emosional mengapa EI lebih penting daripada IQ, Jakarta: PT. Gramedia Pustaka Utama.

Hafid, M., \& Prasetio, A. P. (2017). Pengaruh Work-Life Balance Terhadap Turnover Intention (Studi pada Karyawan Divisi Food \& Beverage Hotel Indonesia Kempinski Jakarta). SMART-Study \& Management Research, 14(3), 54.

Handayani, A., Afiatin, T., \& Adiati, M. G. (2015). Studi eksplorasi makna keseimbangan kerja keluarga pada ibu bekerja. In Prosiding Seminar Psikologi \& Kemanusiaan ( 2015 Psychology Forum UMM. 
Hendrayani, D. (2013). Pengaruh Komitmen Dan Job Insecurity Terhadap Intensi Turnover Pada Operator Garuda Call Center. MIX: Jurnal Ilmiah Manajemen, 3(1).

Hill, E. J., Hawkins, A. J., Ferris, M., \& Weitzman, M. (2001). Finding an extra day a week: The positive influence of perceived job flexibility on work and family life balance. Family relations, 50(1), 49-58.

Kim, H. K. (2014). Work-life balance and employees' performance: The mediating role of affective commitment. Global Business and Management Research, 6(1), 37.

Luthans, F. (2011). Organizational Behavior. New York: McGraw-Hill.

Mahiri, E. A. (2016). Pengaruh Pendelegasian Wewenang dan Komitmen Organisasi Terhadap Prestasi Kerja Pegawai Dinas Pendidikan Kabupaten Majalengka. MAKSI, 3(1).

Majdalani, J. F., \& Maamari, B. E. (2016). Emotional intelligence, a tool for customer satisfaction. Journal for Global Business Advancement, 9(3), 275-283.

Nguyen, V. (2020). Human capital, capital structure choice and firm profitability in developing countries: An empirical study in Vietnam. Accounting, 6(2), 127-136.

Soelton, M., Amaelia, P., \& Prasetyo, H. (2020a). Dealing with job Insecurity, work stress, and family conflict of employees. In 4th International Conference on Management, Economics and Business (ICMEB 2019) (pp. 167-174). Atlantis Press.

Soelton, M., Noermijati, N., Rohman, F., Mugiono, M., Aulia, I., \& Siregar, R. (2020b). Reawakening perceived person organization fit and perceived person job fit: Removing obstacles organizational commitment. Management Science Letters, 10(13), 2993-3002.

Soelton, M. (2020). The implication of job satisfaction that influence workers to practice organizational citizenship behavior (OCB) in the work place. Archives of Business Research, 8(5), 33-48.

Suzabar, D. F., Soelton, M., Umar, M., \& Triwulan, J. (2020, February). Recognizing how the time demands of work influences the turnover intention in banking industry. In 4th International Conference on Management, Economics and Business (ICMEB 2019) (pp. 40-45). Atlantis Press.

McShane, S. L., \& Von Glinow, M. A. (2014). Comportamento Organizacional-6. AMGH Editora.

Mobley, W. H. (2011). Pergantian Karyawan : Sebab, Akibat dan Pengendaliannya (Terjemahan). Jakarta: PT Pustaka Binaman Pressindo.

Moorhead, G., \& Griffin, R. (2013). Organizational Behavior: Managing People and Organization (9th ed.). Mason: South Western Cengage Learning.

Nurhayati, M., Thoyib, A., \& Irawanto, D. W. (2018). Impersonal Trust and Perceived Organizational Politics on Organizational Commitment. European Research Studies Journal, 21(3), 391-403.

Nurhayatia, M., Thoyib, A., \& Noermijati, N. (2017). The Role of Political Skills for Organizational Commitment. International Journal of Economic Perspectives, 11(4), 493-498.

Rene, R., \& Wahyuni, S. (2018). Pengaruh Work-Life Balance Terhadap Komitmen Organisasi, Kepuasan Kerja, Dan Motivasi Kerja Terhadap Kinerja Individu Pada Karyawan Perusahaan Asuransi Di Jakarta. Jurnal Manajemen Dan Bisnis Sriwijaya, 16(1), 53-63.

Rustamadji, R., \& Omar, C. (2019). The effect of strategic management and organizational commitment on employees' work achievement. Management Science Letters, 9(3), 399-412.

Wibowo. (2017). Perilaku dalam Organisasi. Jakarta: Raja Grafindo Persada.

Wirawan. (2015). Manajemen Sumber Daya Manusia Indonesia: Teori, Psikologi, Hukum, Ketenagakerjaan, Aplikasi dan Penulisan : Aplikasi dalam Organisasi Bisnis, Pemerintahan dan Pendidikan. PT. RAJAGRAFINDO PERSADA. Jakarta.

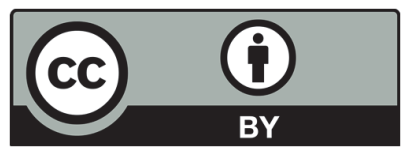

(C) 2020 by the authors; licensee Growing Science, Canada. This is an open access article distributed under the terms and conditions of the Creative Commons Attribution (CC-BY) license (http://creativecommons.org/licenses/by/4.0/). 